\title{
A Case of Solitary Tricholemmoma
}

\author{
Hong-Pu Yang, Dong Liu* \\ Department of Dermatology, Affiliated Hospital of Tianjin Traditional Chinese Medicine Research Institute, Tianjin, China \\ Email: pigmentcell@sina.com
}

How to cite this paper: Yang, H.-P. and Liu, D. (2017) A Case of Solitary Tricholemmoma. Journal of Cosmetics, Dermatological Sciences and Applications, 7, 173176

https://doi.org/10.4236/jcdsa.2017.72015

Received: October 30, 2016

Accepted: June 23, 2017

Published: June 26, 2017

Copyright (c) 2017 by authors and Scientific Research Publishing Inc. This work is licensed under the Creative Commons Attribution International License (CC BY 4.0).

http://creativecommons.org/licenses/by/4.0/

\begin{abstract}
Tricholemmoma is a benign follicular tumor with differentiation towards cells of the outer hair root sheath and usually presents as a small papule on the face in middle-aged or older people. We herein report a case of solitary tricholemmoma located in the lateral right thigh, which shows the appearance of infiltrated plaque. Histopathologic examination is confirmed the diagnosis of tricholemmoma.
\end{abstract}

\section{Keywords}

Tricholemmoma, Skin Neoplasms

\section{Introduction}

Tricholemmomas are benign follicular neoplasms that exhibit differentiation towards the outer root sheath of the pilosebaceous follicular epithelium. It was firstly described by Headington and Prench [1] as a clear cell tumor with differentiation towards the outer root sheath. It consists of superficial lobules of glycogen-rich epithelial cells with peripheral palisading of columnar cells, surrounded by a thickened basement membrane. Tricholemmomas clinically present as individual or multiple, slowly growing, verrucous papules appearing most commonly on the face or neck. The lesions are combined with small plaques. There are no specific clinical presentations of tricholemmoma which is easily misdiagnosed as verrucous pailloma and basal cell carcinoma, etc. Although quite a number cases of tricholemmoma have been reported, to our knowledge, solitary plaque is a rare clinical presentation, so we report here a case of tricholemmoma with a single plaque which simulates basal-cell carcinoma in appearance.

\section{A Case Report}

A 54-year-old man was referred to our department for a 1.5-year history of infiltrated plaque on the lateral right thigh. It occurred as a solitary papule and grew slowly to form a plaque without ulceration and discharge. He has been suffering 
from diabetes for 6 years and we haven't met the similar cases before. He complained of no pain and there are no any other signs or systemic symptoms. A dermatological examination showed a erythematous plaque with a keratotic surface, oval in shape, located in the right thigh area, measuring about $2.5 \mathrm{~cm} \times 2.0$ $\mathrm{cm}$ (Figure 1). Histological examination showed that the tumors consisted of lobules of epithelial cells in continuity with the epidermis and the lobules had well-demarcated margins. The cells toward the center of the lobule were pale staining with uniform nuclei and clear, glycogen-rich cytoplasm. Cells toward the periphery of the lobule appeared basophilic with a palisading arrangement of the peripheral cell. The epidermis showed hyperkeratosis with parakeratosis (Figure 2 \& Figure 3 ). The correlation of clinical findings with histopathology

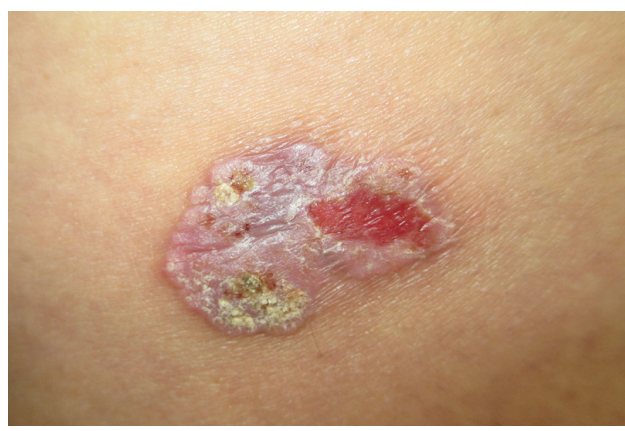

Figure 1. The erythematous plaque with a keratotic surface, oval in shape, measuring about 2.5 $\mathrm{cm} \times 2.0 \mathrm{~cm}$.

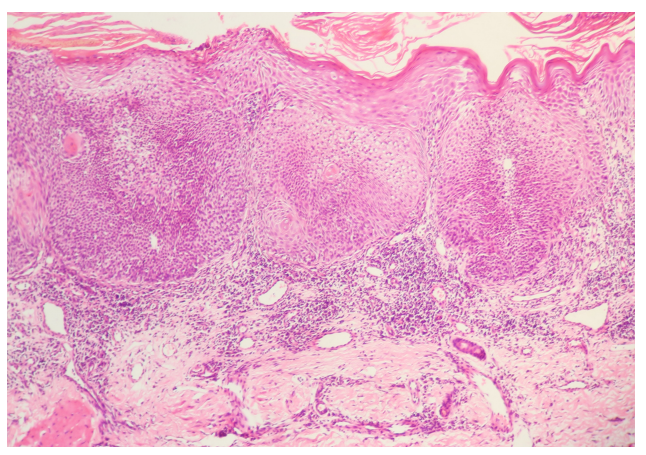

Figure 2. HE. 40×. Tumor lobules connected to the epidermis with well-demarcated margins.

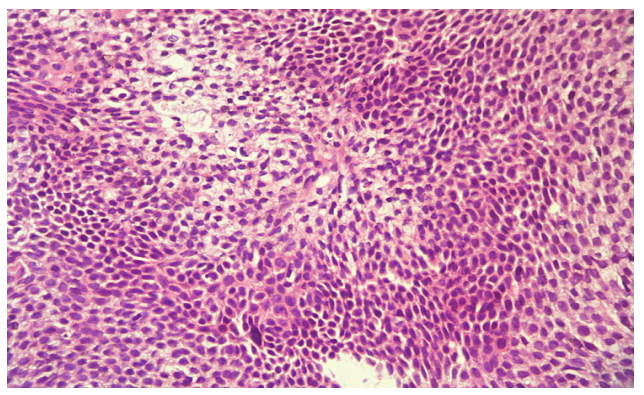

Figure 3. HE. 400×. Histological aspect of clear cells, with the peripheral palisade. 
confirmed the diagnosis of tricholemmoma. The lesion was removed by surgery and has not relapsed until now in the outpatient following-up years.

\section{Discussion}

Tricholemmoma is a benign cutaneous epithelial tumor with differentiation towards cells of the outer hair root sheath. It may be solitary or multiple. The most common type occurs as a small, warty or smooth, skin-colored papule on the face of middle-aged or older people, generally misdiagnosed as a verrucous papilloma. Rarely does it correspond to a cutaneous horn [2]. Multiple tricholemmomas are associated with Cowden syndrome which results from a mutation in the phosphatase and tensin homolog tumor suppressor gene, PTEN [3]. The desmoplastic tricholemmoma is a rare tricholemmoma variant. It is characterized by a pseudo invasive silhouette, which is imparted by the disposition of the stroma. The stroma dissects the epithelial tumor lobules like an invasive carcinoma clinically [4]. Some cases of solitary tricholemmoma may represent a reorganized viral papilloma, as testified by the occasional presence in these cases of signs of cytopathogenic HPV. However, it remains controversial, as well as the molecular finding of HPV in tricholemmomas [5] [6]. Consistent with the tumor's differentiation towards the outer root sheath of the hair follicle, tricholemmomas have been reported to express CD34 focally or diffusely [7]. Recently the high frequency of HRAS activating mutations was detected in tricholemmomas, which suggests most tricholemmomas are authentic neoplasms [8].

Due to non-specific clinical presentations of trichilemmoma, it may look similar to other cutaneous lesions. The differential diagnosis for trichilemmoma includes verruca vulgaris, other benign hair follicle and epidermal tumors. Histopathologic examination is required [9]. Our case of tricholemmoma with plaques clinically simulated basal-cell carcinoma. However, it is easy to make a distinction by histopathologic examination.

Since it is a benign neoplasia, surgical excision is not necessary. However, as it is a rare cutaneous neoplasm and easily mistaken for other invasive cutaneous neoplasms, a complete surgical excision is advised for histopathological examination and diagnostic definition.

\section{Conflicts of Interest}

Not declared.

\section{Funding}

None.

\section{References}

[1] Headington, J.T. and French, A.J. (1962) Primary Neoplasms of the Hair Follicle, Histogenesis and Classification. Archives of Dermatology, 86, 430-441. https://doi.org/10.1001/archderm.1962.01590100044012

[2] Brownstein, M.H. and Shapiro, L. (1973) Trichilemmoma: Analysis of 40 New Cas- 
es. Archives of Dermatology, 107, 866-869.

https://doi.org/10.1001/archderm.1973.01620210034008

[3] Al-Zaid, T., Ditelberg, J., Prieto, V., et al. (2012) Trichilemmomas Show Loss of PTEN in Cowden Syndrome but Only Rarely in Sporadic Tumors. Journal of Cutaneous Pathology, 39, 493-499. https://doi.org/10.1111/j.1600-0560.2012.01888.x

[4] Tellechea, O., Reis, J.P., Domingues, J.C. and Baptista, A.P. (1993) Desmoplastic Trichilemmoma. The American Journal of Dermatopathology, 15, 452-455. https://doi.org/10.1097/00000372-199310000-00007

[5] Leonardi, C.L., Zhu, W.Y., Kinsey, W.H. and Penneys, N.S. (1991) Trichilemmomas Are Not Associated with Human Papillomavirus DNA. Journal of Cutaneous Pathology, 18, 193-197. https://doi.org/10.1111/j.1600-0560.1991.tb00152.x

[6] Stierman, S., Chen, S., Nuovo, G. and Thomas, J. (2010) Detection of Human Papillomavirus Infection in Trichilemmomas and Verrucae Using in situ Hybridization. Journal of Cutaneous Pathology, 37, 75-80.

https://doi.org/10.1111/j.1600-0560.2009.01348.x

[7] Tardío, J.C. (2009) CD34-Reactive Tumors of the Skin. An Updated Review of an Evergrowing List of Lesions. Journal of Cutaneous Pathology, 36, 89-102. https://doi.org/10.1111/j.1600-0560.2008.01212.x

[8] Tsai, J.H., Huang, W.C., Jhuang, J.Y., et al. (2014) Frequent Activating HRAS Mutations in Trichilemmoma. British Journal of Dermatology, 171, 1073-1077. https://doi.org/10.1111/bjd.13143

[9] Tellechea, O., Cardoso, J.C., Reis, J.P., et al. (2015) Benign Follicular Tumors. Anais Brasileiros de Dermatologia, 90, 780-798. https://doi.org/10.1590/abd1806-4841.20154114

\section{Submit or recommend next manuscript to SCIRP and we will provide best} service for you:

Accepting pre-submission inquiries through Email, Facebook, LinkedIn, Twitter, etc. A wide selection of journals (inclusive of 9 subjects, more than 200 journals)

Providing 24-hour high-quality service

User-friendly online submission system

Fair and swift peer-review system

Efficient typesetting and proofreading procedure

Display of the result of downloads and visits, as well as the number of cited articles Maximum dissemination of your research work

Submit your manuscript at: http://papersubmission.scirp.org/

Or contact jcdsa@scirp.org 